\title{
Alkaline phosphatase activity of normal and cystic fibrosis fibroblasts
}

\author{
D A AITKEN* AND A HOOGEVEEN† \\ From *the Department of Medical Genetics, Royal Hospital for Sick Children, Yorkhill, \\ Glasgow G3 8SJ, Scotland; and †the Department of Cell Biology and Genetics, \\ Medical Faculty, Erasmus University, Rotterdam, The Netherlands
}

SUMMARY Alkaline phosphatase (ALP) activities were compared in fibroblasts from three cystic fibrosis patients and two normal controls after culturing the cells in normal growth medium and in medium containing Tamm-Horsfall glycoprotein, isoproterenol, and theophylline. No consistent alterations in ALP activities were noted, either between the same cell lines grown under different conditions, or between normal and cystic fibrosis cell lines. It is concluded that it is not possible to use changes in ALP activity in cultured cells for the prenatal diagnosis of cystic fibrosis.

It has recently been reported that the metabolism of cultured fibroblasts from patients with cystic fibrosis (CF), but not that of heterozygotes or normal controls, can be modified by growing the cells in the presence of a specific urinary glycoprotein, the Tamm-Horsfall glycoprotein (THP). ${ }^{1}$ Data have been presented which show that under these conditions there is induction of alkaline phosphatase (ALP, E.C.3.1.3.1) resulting in an up to seven-fold higher specific activity in CF fibroblasts compared to normal control fibroblasts. ${ }^{12} \mathrm{~A}$ possible mechanism for this induction process has been suggested and a hypothesis on the basic biochemical defect in $\mathrm{CF}$ advanced. ${ }^{3}$

Because of the important implications of this hypothesis for the prenatal diagnosis of this most frequent lethal inherited disease of childhood, we have pursued the observation of induced ALP activity in fibroblast cultures from CF patients, duplicating as closely as possible the culture conditions and microassay techniques described. ${ }^{12}$ In repeated experiments, we have not been able to find reproducible differences in ALP activity between fibroblasts from CF patients and normal subjects.

\section{Materials and methods}

PREPARATION OF

TAMM-HORSFALL GLYCOPROTEIN

Extraction was from urine according to the original method, ${ }^{4}$ except that sodium azide $(0.02 \%$ final Received for publication 15 October 1979 concentration) was included in the collection vessel instead of chloroform as an antibacterial agent. Clean, sterile glassware was used throughout. The final preparation obtained was an almost clear, viscous liquid. Four separate batches were prepared and the concentration of the dissolved glycoprotein measured spectrophotometrically. After removal of a small aliquot for ALP estimation, the remainder of the glycoprotein was stored at $4^{\circ} \mathrm{C}$ with the addition of kanamycin $(100 \mu \mathrm{g} / \mathrm{ml})$ to prevent decomposition through bacterial growth.

\section{FIBROBLAST CULT URES}

Fibroblast cell lines derived from skin biopsies taken from three unrelated female patients with CF (CF1, 8 years; CF2 and CF3, 9 years) and from two healthy adult donors (aged 22 and 24 years) were used in the induction experiments. CF cultures between the 12th and 14th passage and control cultures between the 18th and 20th passage were trypsinised and approximately 150000 cells seeded into $20 \mathrm{~cm}^{2}$ Petriperm (Heraeus) culture dishes. These are disposable petri dishes the bottom of which is formed by a $25 \mu \mathrm{m}$-thick transparent membrane which serves as the culture surface. Three dishes were set up for each cell line and after overnight incubation to allow the cells to attach, the medium was removed and replaced as follows for each cell line: medium A: Ham's F10 with $15 \%$ fetal calf serum (FCS) and penicillin/ streptomycin; medium B: medium A plus $100 \mu \mathrm{g} / \mathrm{ml}$ THP; medium C: medium B plus $1 \times 10^{-5} \mathrm{~mol} / 1$ 
isoproterenol and $1 \times 10^{-3} \mathrm{~mol} / 1$ theophylline. Culture was continued for 72 hours at $37^{\circ} \mathrm{C}$ in a fully humidified atmosphere containing $5 \% \mathrm{CO}_{2}$ in air, with additional doses of isoproterenol (sterilised by filtration) added to medium $\mathrm{C}$ to a final concentration of $1 \times 10^{-5} \mathrm{~mol} / 124$ hours and 48 hours after the beginning of the induction experiment to supplement its rapid oxidation at $37^{\circ} \mathrm{C}$. After 72 hours the medium was removed, the cells washed with isotonic saline, and the dishes shockfrozen in liquid nitrogen and freeze dried. After lyophilisation, the dishes were stored in closed boxes containing silica gel in a temperature and humidity controlled room $\left(20^{\circ} \mathrm{C} ;<40 \%\right.$ relative humidity) until required for ALP assay.

In addition, all three $\mathrm{CF}$ cell lines and one control cell line were set up in triplicate in $25 \mathrm{~cm}^{2}$ Falcon flasks and cultured with normal medium $A$ and both induction media $B$ and $C$ under the same growth conditions as the Petriperm cultures. The cells were harvested after 72 hours by trypsinisation and pellets prepared for ALP assay.

\section{ALKALINE PHOSPHATASE ASSAYS}

ALP activity of freeze dried fibroblasts, cell pellets, and THP preparations was assayed using the artificial substrate 4-methylumbelliferyl-phosphate (Mu)(Koch-Light), final concentration $5.5 \mathrm{mmol} / \mathrm{l}$, in $0.2 \mathrm{~mol} / 1$ 2-amino-2-methyl propandiol buffer pH $9 \cdot 3$, with $0.05 \%$ bovine serum albumin.

The assay of ALP activity in freeze dried fibroblasts was carried out in parafilm microcuvettes (PMC) ${ }^{5}$ containing $0.3 \mu$ l substrate and loaded with 20 freeze dried fibroblasts isolated by free hand dissection of a small piece of the Petriperm membrane carrying the freeze dried cells. After incubation for 2 hours at $37^{\circ} \mathrm{C}$, the reaction was ended by washing the contents of each PMC into $500 \mu$ l carbonate buffer $(0.5 \mathrm{~mol} / 1, \mathrm{pH} 10.7)$ and the liberated fluorescence measured in a Perkin Elmer MPF-2A fluorimeter (excitation $365 \mathrm{~nm}$, fluorescence $448 \mathrm{~nm}$ ).

The cell pellets obtained from the parallel culture experiment in Falcon flasks were disrupted by sonication in $100 \mu$ l distilled water, aliquots were further diluted $1: 10$ with distilled water, and $1.0 \mu l$ aliquots assayed for ALP activity using the same substrate concentration as above in a final volume of $2.0 \mu \mathrm{l}$ under oil. Protein content of the diluted lysates was estimated by the method of Lowry et al. ${ }^{6}$ Additional assays using the same cell lysates were performed with $10.0 \mathrm{mmol} / 1 \mathrm{MgCl}_{2}$ as a component of the substrate solution.

ALP activity was measured in each of the THP preparations using the PMC techniques described above, with $0.3 \mu l$ THP and $0.3 \mu l$ substrate (final substrate concentration as above, but without $\mathrm{MgCl}_{2}$ ).

\section{Results}

A specific ALP activity was found in three THP preparations of $15 \cdot 1,16 \cdot 8$, and $17.9 \mathrm{nmol} \mathrm{Mu} / \mathrm{h} / \mathrm{mg}$ THP, respectively. The level of ALP activity per $\mathrm{ml}$ of an induction medium containing $100 \mu \mathrm{g} / \mathrm{ml}$ of a particular THP preparation is one-tenth of these specific activities. Bacterial contamination in a fourth THP preparation resulted in an approximately 16 times higher level of ALP activity.

Table 1 contains the results of the ALP assays in cell homogenates after induction experiments in the three CF cell lines and one control cell line. Enzyme activity is expressed as $\mathrm{mol} \mathrm{Mu} / \mathrm{h} / \mathrm{dry}$ weight of 20 fibroblasts to facilitate comparisons with the ALP assays in freeze dried cells (table 3 ). The conversion

TABLE 1 ALP activity in freshly prepared cell homogenates of three CF cell lines and one control cell line grown under three different culture conditions

\begin{tabular}{|c|c|c|c|}
\hline & \multicolumn{3}{|c|}{ ALP activity ( $\times 10^{-13} \mathrm{~mol} \mathrm{Mu} / \mathrm{h} / 20$ fibroblasts $)$} \\
\hline & $\begin{array}{l}\text { Medium A } \\
\text { Mean } \pm S D\end{array}$ & $\begin{array}{l}\text { Medium B } \\
M e a n \pm S D\end{array}$ & $\begin{array}{l}\text { Medium } C \\
\text { Mean } \pm S D\end{array}$ \\
\hline $\begin{array}{l}\text { (a) Without } \mathrm{Mg}^{++} \\
\text {Control } 1 \\
\text { CF } 1 \\
\text { CF } 2 \\
\text { CF 3 }\end{array}$ & $\begin{array}{r}10 \cdot 6 \pm 2 \cdot 5 \\
11 \cdot 3 \pm 0.4 \\
8 \cdot 5 \pm 0.2 \\
3 \cdot 6 \pm 0.1\end{array}$ & $\begin{array}{l}4 \cdot 2 \pm 0 \cdot 4 \\
9 \cdot 2 \pm 1 \cdot 4 \\
8 \cdot 0 \pm 1 \cdot 1 \\
3 \cdot 2 \pm 0 \cdot 5\end{array}$ & $\begin{array}{r}5 \cdot 1 \pm 0 \cdot 5 \\
9 \cdot 6 \pm 0 \cdot 5 \\
16 \cdot 2 \pm 0 \cdot 1 \\
4 \cdot 2 \pm 0 \cdot 1\end{array}$ \\
\hline $\begin{array}{l}\text { (b) With Mg } \mathbf{~ g}^{++} \\
\text {Control } 1 \\
\text { CF } 1 \\
\text { CF } 2 \\
\text { CF } 3\end{array}$ & $\begin{array}{r}12 \cdot 3 \pm 1 \cdot 1 \\
19 \cdot 2 \pm 3 \cdot 4 \\
12 \cdot 4 \pm 0 \cdot 3 \\
7 \cdot 7 \pm 0 \cdot 5\end{array}$ & $\begin{array}{r}9.0 \pm 0.5 \\
15 \cdot 2 \pm 1 \cdot 3 \\
8 \cdot 0 \pm 0.6 \\
12.9 \pm 0.2\end{array}$ & $\begin{array}{r}9 \cdot 5 \pm 0.5 \\
16 \cdot 5 \pm 0.7 \\
21 \cdot 0 \pm 1 \cdot 1 \\
8 \cdot 0 \pm 0.1\end{array}$ \\
\hline
\end{tabular}

Each value is the mean of duplicate assays (a) without exogenous $\mathrm{Mg}^{++}$ions in the substrate and (b) with $10.0 \mathrm{mmol} / 1 \mathrm{MgCl}_{2}$.

Culture conditions: medium A: Ham's F10 $+15 \%$ FCS + penicillin/ streptomycin; medium B: medium A+100 $\mu \mathrm{g} / \mathrm{ml}$ THP; medium C: medium $\mathrm{B}+1 \times 10^{-5} \mathrm{~mol} / 1$ isoproterenol $+1 \times 10^{-3} \mathrm{~mol} / 1$ theophylline.

TABLE $2 A L P$ activity in frozen cell lysates of $C F 2$ immediately after thawing and after 48 hours at room temperature

\begin{tabular}{|c|c|c|c|}
\hline & \multicolumn{3}{|c|}{$A L P$ activity $\left(\times 10^{-13} \mathrm{~mol} \mathrm{Mu} / \mathrm{h} / 20\right.$ fibroblasts $)$} \\
\hline & $\begin{array}{l}\text { Medium A } \\
\text { Mean } \pm S D\end{array}$ & $\begin{array}{l}\text { Medium B } \\
\text { Mean } \pm S D\end{array}$ & $\begin{array}{l}\text { Medium } C \\
M e a n \pm S D\end{array}$ \\
\hline \multirow{2}{*}{$\begin{array}{l}\text { (a) Without } \mathrm{Mg}^{++} \\
\mathrm{CF} 2 \text { immediately } \\
\text { after thawing } \\
\text { After } 48 \text { hours at } \\
\text { room temperature }\end{array}$} & $6 \cdot 2 \pm 0 \cdot 5$ & $6 \cdot 3 \pm 0 \cdot 4$ & $13 \cdot 2 \pm 1 \cdot 0$ \\
\hline & $16 \cdot 5 \pm 1 \cdot 6$ & $22 \cdot 8 \pm 3 \cdot 1$ & $22 \cdot 9 \pm 1 \cdot 6$ \\
\hline \multirow{2}{*}{$\begin{array}{l}\text { (b) With } \mathrm{Mg}^{++} \\
\text {CF2 immediately } \\
\text { after thawing } \\
\text { After } 48 \text { hours at } \\
\text { room temperature }\end{array}$} & $8 \cdot 7 \pm 0 \cdot 3$ & $9 \cdot 2 \pm 0 \cdot 2$ & $15 \cdot 6 \pm 0 \cdot 9$ \\
\hline & $19 \cdot 8 \pm 1 \cdot 1$ & $20 \cdot 6 \pm 1 \cdot 6$ & $24 \cdot 9 \pm 2 \cdot 2$ \\
\hline
\end{tabular}

Each value is the mean of 5 independent measurements (a) without exogenous $\mathrm{Mg}^{++}$in the substrate and (b) with $10.0 \mathrm{mmol} / 1 \mathrm{MgCl}_{2}$. 
factor used was $1.0 \mathrm{mg}$ homogenate protein = $3.0 \times 10^{6}$ fibroblasts. ${ }^{7}$ The presence of $\mathrm{Mg}^{++}$ions in the substrate has an activating effect on ALP activity of freshly prepared fibroblast lysates. In one cell line, CF2, there was a marked increase in ALP activity in cells cultured in medium $\mathbf{C}$ containing THP, isoproterenol, and theophylline compared with cells cultured in normal medium A. However, the induction medium B containing $100 \mu \mathrm{g} / \mathrm{ml}$ THP had apparently no particular stimulatory effect on ALP activity in any of the cell lines tested. When ALP activity was retested in three lysates of CF2 which had been stored frozen at $-20^{\circ} \mathrm{C}$, similar relative values were obtained between the three different cultures, both immediately after thawing the sample and at the higher specific activities observed after the thawed sample had been allowed to stand at room temperature for 48 hours (table 2). This time dependent increase in ALP activity of thawed enzyme preparations has been previously reported. ${ }^{8}$

In contrast to the results obtained with cell homogenates, the presence of $\mathbf{M g}^{++}$ions in the substrate was found to have no apparent activating effect on ALP activity of the freeze dried fibroblasts dissected from the Petriperm dishes. The results presented in table 3 have been obtained without $\mathrm{MgCl}_{2}$ in the substrate. One CF cell line (CF2) had increased ALP activity in those cells cultured under conditions intended to be permissive for the induction of ALP (media B and C), but a similar rise also occurred in the two control cell lines and the extent of the increase in activity varies between individual experiments. ALP activities in CF1 and CF3 also appear to be independent of the culture conditions.

TABLE 3 ALP activities in isolated freeze dried fibroblasts from three CF cell lines and two control fibroblast cell lines grown under different culture conditions for 72 hours

\begin{tabular}{|c|c|c|c|c|}
\hline \multirow{2}{*}{$\begin{array}{l}\text { Cell } \\
\text { line }\end{array}$} & \multirow{2}{*}{$\begin{array}{l}\text { Experi- } \\
\text { ment }\end{array}$} & \multicolumn{3}{|c|}{ ALP activity $\left(\times 10^{-13} \mathrm{~mol} \mathrm{Mu} / \mathrm{h} / 20\right.$ fibroblasts $)$} \\
\hline & & $\begin{array}{l}\text { Medium A } \\
\text { Mean } \pm S D\end{array}$ & $\begin{array}{l}\text { Medium B } \\
\text { Mean } \pm S D\end{array}$ & $\begin{array}{l}\text { Medium } C \\
\text { Mean } \pm S D\end{array}$ \\
\hline Control 1 & $\begin{array}{l}\text { (i) } \\
\text { (ii) }\end{array}$ & $\begin{array}{l}7 \cdot 2 \pm 0 \cdot 7 \\
9 \cdot 1 \pm 1 \cdot 8\end{array}$ & $11 \cdot 3 \pm 2 \cdot 2$ & $\begin{array}{l}14 \cdot 8 \pm 1 \cdot 5 \\
12 \cdot 5+1 \cdot 9\end{array}$ \\
\hline Control 2 & $\begin{array}{l}\text { (i) } \\
\text { (ii) }\end{array}$ & $\begin{array}{l}8 \cdot 9 \pm 3 \cdot 1 \\
8 \cdot 6 \pm 0.9\end{array}$ & $\begin{array}{l}14.5 \pm 3.5 \\
12.0+2.6\end{array}$ & $\begin{array}{l}12 \cdot 5 \pm 5 \cdot 2 \\
15 \cdot 0+3 \cdot 0\end{array}$ \\
\hline \multirow[t]{2}{*}{ CF1 } & (i) & $8 \cdot 0 \pm 4 \cdot 9$ & $6 \cdot 0 \pm 3 \cdot 2$ & $7.6 \pm 3.0$ \\
\hline & (ii) & $16 \cdot 6 \pm 1 \cdot 9$ & $18 \cdot 1 \pm 4 \cdot 5$ & $15 \cdot 6 \pm 1 \cdot 5$ \\
\hline \multirow[t]{3}{*}{ CF2 } & (i) & $11 \cdot 3 \pm 2 \cdot 9$ & $15 \cdot 0 \pm 2 \cdot 9$ & $21 \cdot 6 \pm 4 \cdot 4$ \\
\hline & (ii) & $10 \cdot 6 \pm 2.4$ & $14 \cdot 6 \pm 4 \cdot 4$ & - \\
\hline & (iii) & $9 \cdot 8 \pm 1 \cdot 5$ & - & $12 \cdot 8 \pm 2 \cdot 9$ \\
\hline \multirow[t]{2}{*}{ CF3 } & (i) & $13 \cdot 9 \pm 3 \cdot 4$ & $15 \cdot 8 \pm 1 \cdot 7$ & $14 \cdot 8 \pm 3 \cdot 5$ \\
\hline & (ii) & $15 \cdot 0 \pm 1 \cdot 8$ & $13 \cdot 7 \pm 3 \cdot 8$ & $15 \cdot 8 \pm 4 \cdot 0$ \\
\hline
\end{tabular}

Individual ALP activities are the means of 10 independent assays with 20 freeze dried fibroblasts each, measured without exogenous $\mathrm{Mg}^{++}$in the substrate. Each cell line was tested twice (CF2 three times), using different THP preparations in the induction medium.

\section{Discussion}

In our series of cultures, no consistent pattern of induction of ALP emerges similar to that described by Hösli et al, ${ }^{1}$ which would allow a distinction to be made between cultured cells from CF patients and controls. A possible reason for this discrepancy may be minor differences in the composition of the THP or in the presence of impurities, both of which could be crucial to the action of the induction medium. The three THP preparations used in this study were ineffective as ALP inducers. There are also conflicting reports on the influence of isoproterenol stimulation of cyclic AMP in CF cell cultures $^{910}$, which has been proposed as the precursor of the increased ALP activity noted by Hösli and Vogt. ${ }^{2}$ In addition, there may be biochemical differences between fibroblast cultures from different CF patients, but since the biochemical defect responsible for CF has not yet been elucidated, it is not at all certain that the metabolic abnormality is expressed in cultured cells.

While our results show only small and inconsistent changes in ALP activity, interpretation of radically altered enzyme levels may also prove difficult. Generalised increases in leucocyte, but not fibroblast, ALP activity occur in Down's syndrome ${ }^{11}$ and other cases of aneuploidy, while there is decreased ALP activity of leucocytes in chronic myeloid leukaemia; these are just some examples of the unspecific response of ALP to a variety of conditions. Also, there are several reports of raised fibroblast ALP activities in vitro under various modified or suboptimal culture conditions ${ }^{12-14}$; two distinct forms of ALP in fibroblasts have been identified which respond differently to inhibition by L-phenylalanine and activation by $\mathrm{Mg}^{++}$ions. ${ }^{14}$ In addition, very wide ranges of fibroblast ALP using 4-methylumbelliferyl-phosphate as substrate have been reported. Mulivor et $\mathbf{a l}^{\mathbf{1 5}}$ found a range of activity equivalent to 1.5 to $136.6 \times 10^{-13} \mathrm{~mol}$ $\mathrm{Mu} / \mathrm{h} / 20$ fibroblasts in a group of seven normal controls, and Vanneuville et $a^{16}$ of 0.5 to $51.4 \times 10^{-13} \mathrm{~mol} \mathrm{Mu} / \mathrm{h} / 20$ fibroblasts in 33 controls. It is likely that similar wide ranges also exist in CF fibroblasts and in amniotic fluid derived cell cultures.

In conclusion we feel that the qualitative and quantitative variations of fibroblast ALP make it an unsatisfactory parameter of induced biochemical abnormalities in CF cell cultures. In particular, there are inherent dangers in the use of a variable marker (ALP activity) for the detection of a particular gene mutation where the marker is not a direct product or characteristic of the defective gene. 
DAA thanks the Talbot-Crosbie bequest, University of Glasgow, for financial support and Professor Dr $\mathrm{H}$ Galjaard for the facilities to perform these experiments in his laboratory $\dagger$ and for critical reading of the manuscript.

\section{References}

1 Hösli P, Erickson, RP, Vogt E. Prospects for prenatal diagnosis of cystic fibrosis: induction of biochemical abnormalities in fibroblasts from patients with cystic fibrosis by a urinary glycoprotein. Biochem Biophys Res Commun 1976;73:209-16.

2 Hösli P, Vogt E. Reliable detection of cystic fibrosis in skin derived fibroblast cultures. Hum Genet 1978;41:169-73.

3 Hösli P, Vogt E. Cystic fibrosis: leakage of lysosomal enzymes and of alkaline phosphatase into the extracellular space. Biochem Biophys Res Commun 1977;79: 741-8.

4 Tamm I, Horsfall FL Jr. A mucoprotein derived from human urine which reacts with influenza, mumps and Newcastle disease viruses. J Exp Med 1952;95:71-97.

5 Hösli P. Quantitative assays of enzyme activities in single cells: early prenatal diagnosis of genetic disorders. Clin Chem 1977;23:1476-84.

- Lowry OH, Rosebrough NJ, Farr AL, Randall RJ. Protein measurement with the folin phenol reagent. $J$ Biol Chem $1951 ; 193: 265-75$.

7 Galjaard H, Hoogeveen A, Keijzer W, De Wit-Verbeek E, Vlek-Noot C. The use of quantitative cytochemical analyses in rapid prenatal detection and somatic cell genetic studies of metabolic diseases. Histochem J 1974; 6:491-509.
8 Brojer B, Moss DW. Changes in the alkaline phosphatase activity of serum samples after thawing and after reconstitution from the lyophilized state. Clin Chim Acta $1971 ; 35: 511-3$.

- Buchwald M. Abnormal levels of $3^{\prime}: 5^{\prime}$-cyclic AMP in isoproterenol-stimulated fibroblasts from patients with cystic fibrosis. Proc Natl Acad Sci USA 1976;73:2899-903.

10 Davis PB, Braunstein M, Jay C. Decreased adenosine $3^{\prime}: 5^{\prime}$-monophosphate response to isoproterenol in cystic fibrosis leukocytes. Pediatr Res 1978; 12:703-7.

11 Nadler HL, Inouye T, Justice P, Hsia DYY. Enzymes in cultivated human fibroblasts derived from patients with Down's syndrome (mongolism). Nature 1967;213:1261-2.

12 Cox RP, Pontecorvo G. Induction of alkaline phosphatase by substrates in established cultures of cells from individual human donors. Proc Natl Acad Sci USA 1961; 47:839-45.

18 Lundgren E. Conditions for induction of alkaline phosphatase in cultured human fetal skin fibroblasts. Exp Cell Res 1977;110:25-30.

14 Vanneuville FJ, Van Elsen AF, Leroy JG. Alkaline phosphatase: properties in crude homogenates of human diploid fibroblasts. Biochem Soc Trans 1977;5:1117.

16 Mulivor RA, Mennuti M, Zackai EH, Harris H. Prenatal diagnosis of hypophosphatasia: genetic, biochemical, and clinical studies. Am J Hum Genet 1978;30:271-82.

16 Vanneuville FJ, Van Elsen AF, Leroy JG. Alkaline phosphatase: presence and behaviour in human diploid fibroblasts. Arch Int Physiol Biochim 1975;83:1017-8.

Requests for reprints to Dr D A Aitken, Department of Medical Genetics, Royal Hospital for Sick Children, Yorkhill, Glasgow G3 8SJ. 